\title{
Metafora ograniczona?
}

\author{
Agnieszka Kluba
}


- jest najciekawsza w tych miejscach, w których Nowa Fala zostaje zastąpiona przez nowofalowych (albo: niegdyś nowofalowych) poetów. Proszę wybaczyć banał: Nowa Fala współtworzyła klimat intelektualny, moralny, polityczny i literacki lat siedemdziesiątych i (w pewnej mierze) osiemdziesiątych; natomiast: w ważnych przemianach poezji ostatnich trzydziestu lat uczestniczyli niektórzy związani z tą formacją twórcy. Rozróżnienie tych dwu sytuacji jest sprawą istotną, tym bardziej, iż najpiękniejsze wiersze Barańczaka, Krynickiego, Zagajewskiego nie mieszczą się w granicach dykcji nowofalowej... Nigdy nie zapomnę pierwszej lektury tomu (ściślej: maszynopisu) Ja wiem, że to niestuszne - ale Widokówka z tego świata to poezja znacznie wyższej miary; zachowam w pamięci poematy z Organizmu zbiorowego — znacznie bliższe są mi jednak niektóre bliskie milczeniu wiersze z Niepodległych nicości...

Tylko tyle mogę powiedzieć o Określonej epoce. Chociaż: nie tylko to mógłbym powiedzieć o nowofalowych poetach...

Marian Stala

\section{Metafora ograniczona?}

Problematyka metafory, jak słusznie zauważa we wstępie autorka zbioru szkiców pt. Mówiąc przenośnie..., Teresa Dobrzyńska', od wielu lat stanowi przedmiot zainteresowania specjalistów różnych dziedzin. Nic - zgodnie zresztą ze sformułowaną w 1978 roku przez W. C. Bootha ironiczną przepowiednią ${ }^{2}$ - nie wskazuje, aby popularność tego zagadnienia miała ulec wyczerpaniu. Pomimo optymistycznego ogłaszania coraz nowszych propozycji

1 T. Dobrzyńska Mówiq̨c przenośnie... Studia o metaforze, Warszawa 1994. Cytaty lokalizowane będą za pomocą skrótu MP wraz z numerem strony.

2 W. C. Booth Metaphor as Rhetoric: the Problem of Evaluation, „Critical Inquiry”, 1978, vol. 5, nr 1; ustalił on, że w roku 1977 było więcej tekstów o metaforze niż wszystkich dotychczasowych wypowiedzi na ten temat. Obliczył również, że - przy założeniu tego tempa w 2039 roku zajmujących się metaforą będzie więcej niż ludzi. Dodać warto, że od przywołania tych właśnie przewidywań rozpoczęli swoje wypowiedzi Michał Głowiński i Janusz Sławiński pierwszy podczas sesji o metaforze w 1979 roku, drugi we wprowadzeniu do poświęconego metaforze 6 numeru „Tekstów” z 1980 roku. Obaj przesądzili tym samym o przemianie „prognozy" W. C. Bootha w swoisty topos krytyczny. O takim właśnie topoicznym charakterze swojego stwierdzenia „wzrostu zainteresowania zjawiskiem metafory” mówi także Teresa Dobrzyńska. 
modeli metafory, zdaje się, że ich projektodawcy ulegają sile własnych życzeń i utopii. Okupując zakreślone przez siebie obszary, razem wypracowują wielokształtny i eklektyczny metodologicznie opis, będący - jak można przypuszczać - jedynie możliwą formą refleksji w tej sprawie.

A jeśli tak, jeśli przyjąć za normę równoprawne istnienie wielu koncepcji metafory, staje się oczywiste, że żaden nowy głos nie uniknie konfrontacji z innymi. Świadomość tych okoliczności towarzyszyła zapewne Dobrzyńskiej. Poznać to łatwo po częstokroć powtarzanych przez nią zastrzeżeniach, świadczących o chęci uprzedzenia zarzutów pomijania tych lub innych perspektyw badawczych. I tak we wstępie zapowiada badaczka zamiar ukazania „mechanizmu sensotwórczego przenośni, jego uwikłania w tekście i jego funkcji komunikacyjnych" [MP, s. 6]. Zarazem wyraża Dobrzyńska przckonanie, że pragmatyka lingwistyczna jest dogodnym punktem startu rozważań zmierzających do ,analiz funkcji metafory w tekście literackim”. Wobec tylu deklaracji potrzeby badania metafory $z$ różnych punktów widzenia dziwi jednak fakt braku odniesienia do klasycznej już pozycji w polskiej „metaforologii", tj. dwutomowych Studiów o metaforze, zbierających efekty dwu konferencji jej poświęconych ${ }^{3}$.

Bezpośrednio przywołuje natomiast autorka własną monograficzną rozprawę pt. Metafora ${ }^{4}$ - jako miejsce zalążkowego pojawienia się niektórych wątków teraz przez nią rozwijanych. Na łączność z tą publikacją wskazują także daty powstania rozpraw składających się na omawiany tom. Trzy z sześciu pochodzą z lat 1986-1988, a więc z okresu następująccgo bezpośrednio po wydaniu monografii. Dotyczą one językowych i kulturowych uwarunkowań metafory oraz jej porównania $z$ katachrezą. Trzy dalsze poruszają zagadnienia nowe: problem zachowania się przenośni w mowie zależnej, kwestie związane $\mathrm{z}$ tłumaczeniem wypowiedzi metaforycznych oraz ich funkcją wartościującą w gatunkach „publicznych” - w dyskursie publicystycznym i politycznym. Wszystkie rozprawy pochodzą z wydanych wcześniej tomów zbiorowych. Na użytek omawianej publikacji zostały one zmienione i poszerzone.

Podkreślony w podtytule - Studia o metaforze — luźny charakter

3 Studia o metaforze, I. red. E. Sarnowska-Temeriusz, Wrockaw 1980; Studia o metaforze II, red. M. Głowiński, A. Okopień-Sławińska, Wrocław 1983.

4 T. Dobrzyńska Metafora, red. M. R. Mayenowa, seria Poetyka. Zarys encyklopedyczny, t. IV, z. 1, Wrocław 1984. 
zbioru nie oznacza kompozycji zupełnie dowolnej, pozbawionej wewnętrznej hierarchii. Szczególne znaczenie posiada praca pierwsza Interpretacja wypowiedzi metaforyczmych, polecana przez autorkę w słowie wstępnym jako merytoryczne wprowadzenie do dalszych rozważań. Nadrzędność wynika z przedstawionego tam „modelu sensotwórczego mechanizmu metafory". Stanowi on modyfikację rozwiązania zawartego we wspomnianej już monografii.

Dobrzyńska poświęciła wiele swoich prac teorii tekstu. Zjawisko metafory stanowi dla tej dziedziny wyjątkowe wyzwanie jako ucieleśnienie problemu dla niej podstawowego. Podobnie jak zdania poetyckie dla generatywistów, tak teksty literackie dla badaczy „gramatyki tekstu" wymykają się uniwersalizującym ujęciom, wykazując nieuchwytną zdolność sensotwórczego naruszania kodu. Z tego punktu widzenia zrozumiała wydaje się chęć ujarzmienia tropu będącego zawsze figurą niespójności.

U podstaw swej koncepcji umieszcza Dobrzyńska założenie komunikacyjnego zdeterminowania metafory i decyduje się na jej przedstawianie ,Z perspektywy odbiorcy tekstu”. Model mechanizmu metafory okazuje się modelem procedury interpretacyjnej, podejmowanej przez odbiorcę dla przywrócenia zakłóconej spójności tekstu. Zaprezentowanemu schematowi ${ }^{5}$ towarzyszy opis trzech stopni czynności interpretującego: identyfikacja „tematu głównego”, czyli podmiotu metafory, wskazanie cech (konotacji) "tematu pomocniczego" oraz wybór tych $\mathrm{z}$ nich, które w danym przypadku można odnieść do podmiotu. Za podstawowy warunek fortunności pierwszego i trzeciego kroku uznaje Dobrzyńska znajomość kontekstu, obejmującego zarówno stosunki wewnątrztekstowe, jak i sytuację komunikacyjną. Powodzenie etapu drugiego zależy od posiadania przez odbiorcę kompetencji kulturowych.

Nie zaprzeczając słuszności tych ustaleń, trzeba zauważyć, że zatrzymują się one w połowie drogi. Gdy zgodzimy się, że „wartości konota-

5 X jest ...

Aby powiedzieć, jaki jest X, myślę o Y-u, ponieważ o X można powiedzieć to, co mówi się o Y-u.

$Y$ jest $y^{\prime} \rightarrow X$ jest $y^{\prime}$

$Y$ jest $y^{\prime \prime} \rightarrow X$ jest $y^{\prime \prime}$

$Y$ jest $y^{\prime \prime \prime \prime} \rightarrow$

$Y$ jest $y^{\prime \prime \prime \prime} \rightarrow X$ jest $y^{\prime \prime \prime \prime}$

itd. itd. X oznacza podmiot wypowiedzi; Y - ,inny przedmiot", którego cechy przenosi się na $X^{\prime \prime} ; y^{\prime}, y^{\prime \prime}$ - predykaty, dające się przypisać Y-owi. „Strzałki” symbolizują przenoszenie konotacji Y-a na X." [MP. s, 15) (Cudzysłów wyróżnia określenia autorki). 
cyjne nie są dane jako zamknięty ustalony szereg", oraz uznamy w konsekwencji nieuchronność ,,semantycznego rozchwiania" pomiędzy poszczególnymi efektami interpretacyjnymi, będziemy musieli zapytać o to, jakiego rodzaju moce wewnątrz- i zewnątrztekstowe decydują o uwzględnieniu tych, a nie innych konotacji. Nawet pozostawienie tej kwestii jako otwartej, bo nierozstrzygalnej wymagałoby uściślenia takiego sądu. To niedopowiedzenie jest charakterystyczną cechą rozwiązań generalizujących i nieodmiennie natrafiających na procesy, których złożoność i „wrodzona” niekonkluzywność z góry wszelkie uogólnienia udaremnia.

Moją próbę wyjaśnienia tej - nie dającej się uniknąć w koncepcjach normatywnych - niekonsekwencji chciałabym wesprzeć zaproponowanym przez Włodzimierza Boleckiego rozróżnieniem faktu i sytuacji, których dualizm nazwał on podstawowym problemem epistemologicznym XX wieku. Dla metodologii oznacza to „niemożność przezwyciężenia odrębności między faktem (językiem, tekstem, poetyką) a sytuacją (czytanie, komunikacja)" Propozycja rozumienia metafory, zawarta w omawianym tomie, zmierza do ujęcia kompromisowego: mowa jest tu o kategoriach komunikacyjnych i o płaszczyźnie tekstowej, pamięci długo- i krótkoterminowej, „wiedzy wspólnejö i łańcuchach tematyczno-rematycznych. Rzecz jednak nie tyle w braku uzasadnienia dla takich połączeń, ile w daremności nadziei na ich ogarnięcie jedną formułą wyjaśniającą. Ujęcie pozalingwistycznej spójności metafory, jej „interpretacja semantyczna jest niewykonalna w ramach właściwego językoznawstwa"7, innymi słowy wymaga zupełnie innego metajęzyka, takiego, który mógłby sprostać każdorazowemu (tj. każdokontekstowemu) zaistnieniu metafory. Nie ulega chyba wątpliwości, że wyzwanie to podjąć może jedynie niewyczerpany wysiłek interpretacyjny, zręczne reagowanie na kolejne prowokacje ze strony niestrudzonej w sprawdzaniu wytrzymałości kodu językowego metafory. Autorka omawianego studium, pomimo deklarowanej chęci dostarczenia narzędzi analizy tekstu literackiego, nie wykracza w swoich rozpoznaniach poza horyzont, zakreślony przez punkt widzenia lingwisty. Ilustruje tę prawidłowość rozdział poświęcony katachrezie. W swoich rozważaniach badaczka opowiada się za koniecznością jej

6 W. Bolecki Spójność tekstu (literackiego) jest konwencja, w: Teoretycznoliterackie tematy i.problemy, Wroctaw 1986, s. 165.

7 T. A. van Dijk Some Problems of Generative Poetics, przeł. P. Graff, „Pamiętnik Literacki",1975 z. 1, s. 249. 
odróżniania od metafory. Przyjmuje, że odbiór tej ostatniej zawsze związany jest $z$ interakcją znaczenia kodowego i danego użycia, wywołującą za każdym razem pewne semantyczne napięcie. Zjawisko katachrezy językowej (inopiae causa) przedstawia jako wypełniające lukę w kodzie nowe zastosowanie danego słowa, które posiada już pewną referencję. Dobrzyńska nazywa ten mechanizm swoistym bricolage'em językowym człowieka, "gwarantującym życie języka”. Pomimo tej kwalifikacji zarówno w samych rozważaniach, jak i w warstwie egzemplarycznej zajmuje się przede wszystkim katachrezami, których efekty przyjęły już postać zleksykalizowaną, ustanawiającą polisemiczny charakter danej jednostki językowej. Pomija natomiast problem funkcjonowania katachraz doraźnych, jednorazowych, będących wyzwaniem podczas lektury tekstu literackiego.

Przyjęcie tego rodzaju preferencji legitymizować ma odróżnienie katechrezy od metafory. W takim ujęciu niemożliwy jest jednak opis swoistej współpracy funkcji metaforycznych i katachrestycznych, realizowanej na przykład w prozie Schulza ${ }^{8}$. Bywa tam, że przenośnia, posiadająca w pełni czytelną motywację, w miarę rozwoju tekstu ,prowokuje" krzyżowanie się oddalonych od siebie pól tematycznych. Polega ono najczęściej na adaptowaniu pewnego słownictwa do opisu przedmiotu w potocznym rozumieniu odległego - dzięki temu odsłania Schulz jego nowe, nienazwane przedtem właściwości. Od rozpoznania owej komplementarności procesów metaforycznych i katachrestycznych zależy często uzyskanie wrażenia jedności i spójności znaczeniowej w ramach poszczególnych fragmentów utworu. Trudno zgodzić się wobec tego $\mathrm{z}$ tezą, że „katachreza jest zjawiskiem zachodzącym w obrębie jednostek znaczeniowych (...), funkcjonujących na prawach pojedynczego znaku, metafora może być natomiast realizowana przez całe zdanie." (MP, s. 60).

Nie można nie zauważyć, że słuszna intencja udostępnienia wyników pragmatyki lingwistycznej dla badań nad tekstami literackimi wymaga uwzględnienia tych opracowań, których autorzy jako pierwsi w polskim literaturoznawstwie wykorzystali w udany sposób narzędzia wypracowane teoretycznie dla potrzeb historii literatury". Brak odnie-

8 Por. na ten temat: W. Bolecki Poetycki rodzaj prozy $w$ dwudziestoleciu międzywojenrym, Wrocław 1982, s. 215-217.

y Por. J. Sławiński Koncepcja języka poetyckiego Awangardy Krakowskiej, Wrocław 1965, o metaforze - s. 48-70; Z. Lapiński „Świat caly - jakże zmieścić go w żenicy” (O kategoriach percepcyjnych w poezji Juliana Przybosia), w: Studia z histoni i teorii poezji. seria 2, o roli metaforyzacji - s. 316317; A. Okopień-Sławińska Semantyka wyowiedzi poetyckiej (preliminaria), Wrocław 1985. 
sienia do tych wcześniejszych prac, omawiających kwestię miejsca metafory w tekście poetyckim zawęża nieuchronnie krąg odbiorców tej książki.

Jak już wspomniałam, zbiór zawiera sześć samodzielnych rozpraw przyczynków o dużym rozpięciu tematycznym. Jednym z kierunków zainteresowania Dobrzyńskiej stały się kwestie relacjonowania wypowiedzi metaforycznych w mowie zależnej. Badaczka formułuje tezę o różnych rodzajach uprzedmiotowienia wypowiedzi w oratio recta i w oratio obliqua. Polega ono na tym, że w mowie niezależnej zachodzi dosłowna imitacja formy, a w mowie zależnej — wtórnej reprodukcji ulega treść. Dobrzyńska przypomina - analizuje w tym celu ciąg przykładów - że owymi transformacjami rządzi zasada pragmatyczna, która każdorazowo w przypadku zmiany nadawcy wypowiedzi wymaga weryfikacji jej kształtu językowego ${ }^{1 \prime \prime}$. Naruszanie formy dla zachowania treści okazuje się procedurą szczególnie niewdzięczną w przypadku wyrażeń metaforycznych. Przy okazji omawiania różnych sposobów tworzenia formuł maksymalnie wobcc metafory ekwiwalentnych przywołany zostaje podział Wołoszynowa na „modyfikację przedmiotowo-analityczną" oraz "słowno-analityczną"11. Ta ostatnia zapewnia zwrotowi metaforycznemu nienaruszalność poprzez zastosowanie cudzysłowu. Dobrzyńska uświadamia na koniec, że „formy relacjonowania mowy cudzej są jedną z istotnych technik komunikacyjnych" (MP, s. 50), wciąż czekających na dogłębne zbadanie. Szczególną pomoc w ich analizie widzi ona w koncepcji Grice'a i we współczesnej koncepcji komunikacji.

Jedną ze swych rozpraw wykorzystuje Dobrzyńska na przeprowadzenie polemiki $z$ tezą Teda Cohena ${ }^{12}$, twierdzącego, że motywacją użyć przenośnych jest chęć osiągnięcia przez uczestników komunikacji wrażenia wspólnoty. Badaczka odpowiada kontrtezą, głoszącą, że owo poczucie bliskości nadawcy i odbiorcy jest warunkiem, a nie celem skutecznego kontaktu językowego. Zaznacza dodatkowo, że nie przeszkadza jej to w akceptowaniu kooperacyjnych mechanizmów komunikacji przenośnej opisanych przez H. P. Grice'a. Choć nie znam artykułu Cohena, wydaje mi się, że koncepcje te nie muszą się

10 Oto jeden z podawanych przykładów: „Jan powiedział: Będę tam jutro. $\rightarrow$ Jan powiedzial, że będzie w miejscu przez siebie wskazanym następnego dnia (w stosunku do mówienia tego przez Jana)." (MP., s. 35).

11 W. N. Wołoszynow Marksizm i filozofija jazyka, Leningrad 1930.

12 T. Cohen Metaphor and Cultivation of Intimacy, „Critical Inquiry”, 5, Autumn 1978. 
wykluczać; w tym ujęciu metafora spełniałaby dwie funkcje - weryfikatora stanu kulturowej tożsamości i sposobu jej afirmującego wzmacniania. Być może jest to w rzeczywistości jeden mechanizm, wykształcony przez język dla wiecznego samopotwierdzania.

Sytuacją, podczas której kulturowe uwikłania poszczególnych języków ulegają wyjątkowemu uobecnieniu jest translacja. W przypadku metafory, będącej zawsze złożonym aktem znaczeniotwórczym, ujawnia się to w sposób szczególnie dobitny. Problemy związane $z$ jej przekładem dzieli Dobrzyńska na trzy grupy: (w obu językach) rozmijanie się pól konotacyjnych jednostek leksykalnych, konsekwencje wynikające $\mathrm{z}$ relacji wewnątrzkodowych wyrażeń metaforycznych oraz kwestia funkcjonowania metafor w danym tekście. Omawianiu tych zagadnień poświęca autorka kolejne podrozdziały tej najdłuższej rozprawy, a jej szczegółowość wymagałaby równie dokładnego osobnego omówienia. Artykuł ostatni zwraca uwagę na sposób istnienia metafor w dyskursie o wyraźnym adresie nadawczym, tj. w wypowiedziach publicystycznych i politycznych. Dobrzyńska podkreśla cechy charakterystyczne metafor pojawiających się w tego rodzaju komunikatach - wykorzystywanie stereotypowych skojarzeń, unikanie nietypowych konstrukcji właściwych dla tekstów artystycznych, jednym słowem stosunkowa łatwość w odbiorze. Wskazując na oczywiste powody atrakcyjności stosowania tego tropu w mowie perswazyjnej, tj. skrótowość i dostępność poznania poprzez metaforę, jej właściwości umożliwiające kierowanie tym poznaniem, autorka wyjaśnia, że właściwym powodem podjęcia tego tematu była chęć podzielenia się kilkoma obserwacjami. Dotyczą one m.in. uchwycenia praktyki generowania nowych metafor na podstawie wcześniej znanej konstrukcji pojęciowej, co prowadzi do powstawania swoistych rodzin metafor, zjawiska opisanego sugestywnie przez George'a Lakoffa i Marka Johnsona ${ }^{13}$.

Różnorodność poruszanych przez Dobrzyńską zagadnień odsłania przestrzeń, w jakiej żyje metafora. Jej rozległość przesądza o sposobach uprawiania refleksji na temat tego zjawiska. Książka Teresy Dobrzyńskiej, Mówiąc przenośnie..., dowodzi, że mimo wszystko, mówiąc o sprawach różnych da się powiedzieć więcej niż mówiąc wiele tylko o jednej.

Agnieszka Kluba

13 G. Lakoff, M. Johnson Metaphors We Live By, Chicago 1980; Metafory w naszym życiu, przeł. T. P. Krzeszkowski, Warszawa 1988. 